\title{
Evaluation of Substrates for Mass Culture of Phaeoacremonium parasiticum, the Fungus Responsible for Artificial Oleoresin Deposition in Agarwood Plant
}

\author{
Thi Kim Loan Le, K. C. Puzari, Pranab Dutta* \\ Department of Plant Pathology, Assam Agricultural University, Jorhat, India \\ Email: * pranabdutta74@gma il.com
}

How to cite this paper: Le, T.K.L., Puzari, K.C. and Dutta, P. (2017) Evaluation of Substrates for Mass Culture of Phaeoacremonium parasiticum, the Fungus Responsible for Artificial Oleoresin Deposition in Agarwood Plant. American Journal of Plant Sciences, 8, 2379-2386.

https://doi.org/10.4236/ajps.2017.810160

Received: August 6, 2017

Accepted: September 9, 2017

Published: September 12, 2017

Copyright $\odot 2017$ by authors and Scientific Research Publishing Inc. This work is licensed under the Creative Commons Attribution International License (CC BY 4.0). http://creativecommons.org/licenses/by/4.0/

\begin{abstract}
For establishing the favourable media for growth of Phaeoacremonium parasiticum, the fungus was inoculated in five different media (Potato Dextrose Broth (PDB), Host Extract (50\%) + PDB (50\%) (HE + PDB), and the solid media viz., Rice Bran (RB), Maize Meal (MM) and Wheat Bran (WB)) at $\mathrm{pH}$ of 6.5 and incubated at a temperature of $30^{\circ} \mathrm{C} \pm 1^{\circ} \mathrm{C}$. The solid media were added with water at the rate of $70 \mathrm{ml} / 100 \mathrm{~g}$ of solid substrate. After 30 days of inoculation, conidial population of $P$. parasiticum in liquid media was lower compared to conidial population in solid media. In solid media, MM media showed the highest conidial population $(9.56 \mathrm{log} \cdot \mathrm{cfu} / \mathrm{g})$ followed by WB $(9.50$ $\log \cdot \mathrm{cfu} / \mathrm{g})$ and RB (9.38 log.cfu/g). Hence, Maize Meal media (MM: Water = $100 \mathrm{~g}: 70 \mathrm{ml}$ ) at $\mathrm{pH}$ of 6.5 , incubation temperature: $30^{\circ} \mathrm{C} \pm 1^{\circ} \mathrm{C}$ for 30 days would be the standard technique for mass production of $P$. parasiticum.
\end{abstract}

\section{Keywords}

Phaeoacremonium parasiticum, Agarwood, Standardization, Mass Culture, Media

\section{Introduction}

Agarwood, also known as $U u d$, Oodh, Agar or Gaharu, is the dark resinous heartwood that forms in Aquilaria and Gyrinops trees known as Agar trees. Until recently, Agarwood was primarily produced from Aquilaria malaccensis [1] for three principal uses like medicine, perfume and incense. The international trade in Agarwood involves wood, wood chips, powder and oil [2]. It is used in mos- 
ques and burned to honor guests as well as burned in preparation for prayer [3]. More modern studies confirmed that, Agarwood has bioactive products that function as effective anti-microbial compounds. Agarwood may have anticancer activity, and can be used as an antidepressant and used to promote good health [4] [5]. The global perfume industry has become interested product, and Agarwood has also caught the interest of esoteric circles of non-Asian societies. Agarwood has become the most expensive perfumery raw material in the world and its value surpasses the value of gold [6]. The price of Agarwood is from few dollars per kilogram to over 30,000 US dollars for top quality resinous wood in international market [7]. Seeking and cutting down the tree for harvesting Agarwood has made the Agar trees in nature reduced. To meet the demand of supplying to the market, lots of Agar plants have been grown from small scale at farmer house to large scale in farm.

Even they have highly useful and highly economic value, but unfortunately, in natural forests, the Agar tree only produces oleoresin when it is infected by fungus and only $7 \%-10 \%$ of the trees are infected by the fungus [8]. The other report showed that in fact, only $1 \%$ of Agar trees in nature contain the resinous Agarwood substance [9]. Currently, various researches and investigations concluded that the oleoresin forming in Agar tree relates to the certain contaminated factors combine with certain conditions [2]. The resin production is response to fungal infection and Phaeoacremonium parasiticum is one of the known fungi reported to be associated with Agarwood formation [1] [10] [11]. Its pathogenesis was confirmed and the technique for its isolation and in-vitro culture method has been developed. The result also showed that conidial population density of P. parasiticum in Potato Dextrose Broth was $6.24 \mathrm{log} \cdot \mathrm{spore} / \mathrm{ml}$ and material used for mass culture was costly [12]. Hence, study of evaluation of substrates for mass culture of Phaeoacremonium parasiticum was done to achieve the maximum potential sporulation of $P$. parasiticum with acceptable cost.

\section{Materials and Methods}

\subsection{Evaluation of Media for Mass Culture of $P$. parasiticum}

The media included the liquid media viz., Potato Dextrose Broth (PDB), Host Extract (50\%) + Potato Dextrose Broth (50\%) (HE + PDB), and the solid media viz., Rice Bran (RB), Maize Meal (MM), Wheat Bran (WB). The solid media were added with water at the rate of $70 \mathrm{ml} / 100 \mathrm{~g}$ of solid substrate. $\mathrm{pH}$ was adjusted at 6.5 by adding $\mathrm{HCl}$ or $\mathrm{NaOH}$. Mycelial disc of $7 \mathrm{~mm}$ diameter size was cut with the help of cork-borer from 30 days old of $P$. parasiticum. Substrates were inoculated with freshly cultured mycelial disc and inoculated media were incubated in BOD incubator (ICT) at $30^{\circ} \mathrm{C} \pm 1^{\circ} \mathrm{C}$. The treatments were replicated 5 times. The log.cfu/g or log.spore/ml was counted after 30 days of inoculation by pour plate method in PDA plates, to identify the media in which the fungus have the highest inoculum. Haemocytometer was used to count the 
$\log \cdot$ spore/ml of liquid media.

\subsection{Calculation of Colony Forming Unit (CFU)}

The colony forming units per petriplate were counted with the help of the marker (25 petriplates were counted per treatment). Number of colony forming unit per $\mathrm{g}$ or $\mathrm{ml}$ of sample was calculated follow the formulation [13] as below and converted $\log$ values.

Number of colony forming unit/g or $\mathrm{ml}$ of sample $=($ Number of cfu/plate $) \times$ (reciprocal of dilution of sample).

\section{Results and Discussion}

Phaeoacremonium parasiticum in MM and WB media grew faster and covered all the media in conical flask after 22 days of inoculation (Figure $1(\mathrm{~b})$ and Figure 1(c)). The back side of conical flask of MM media changed to black associated with white colour (Figure 1(b)) and colour of the back side of conical flask of WB media was white (Figure 1(b)). In RB media, at 30 days of inoculation, growth of fungus could not cover full the medial surface (Figure 1(a)). Growth of $P$. parasiticum was very slow in liquid media compared to solid media (Figure 1(d) and Figure 1(e)).

Ajello et al. [14] showed cardinal temperatures for $P$. parasiticum growth as $15^{\circ} \mathrm{C}$ (minimum), $25^{\circ} \mathrm{C}$ (optimum), and $35^{\circ} \mathrm{C}$ (maximum). The other study suggested that discrepant optimal growth temperatures have been obtained for $P$. parasiticum, ranging from $25^{\circ} \mathrm{C}-30^{\circ} \mathrm{C}$ and the optimum was closer to $30^{\circ}$ than to $25^{\circ} \mathrm{C}$ [15]. Akhila et al. [12], after trying incubating $P$. parasiticum at temperature viz., $25^{\circ} \mathrm{C} \pm 1^{\circ} \mathrm{C}, 27^{\circ} \mathrm{C} \pm 1^{\circ} \mathrm{C}, 30^{\circ} \mathrm{C} \pm 1^{\circ} \mathrm{C}$ and $32^{\circ} \mathrm{C} \pm 1^{\circ} \mathrm{C}$ in PDA media, concluded that optimal growth temperature of $P$. parasiticum was $30^{\circ} \mathrm{C} \pm 11^{\circ} \mathrm{C}$. Also in the same study, the optimum growth $\mathrm{pH}$ of $P$. parasiticum was suggested at 6.5 after trying at $\mathrm{pH}$ viz., 5.0, 5.5, 6.0, 6.5 and 7.0. Based on the previous studies, the temperature for growth of $P$. parasiticum was set at $30^{\circ} \mathrm{C} \pm 1^{\circ} \mathrm{C}$ and $\mathrm{pH}$ was set at 6.5 for the present study.

The result of population density ( $\mathrm{cfu} / \mathrm{g}$ or $\mathrm{ml}$ ) count showed that, in liquid media, PDB supported the highest growth with $7.23 \mathrm{log} \cdot \mathrm{cfu} / \mathrm{ml}$ followed by $\mathrm{HE}+$ PDB with $4.85 \mathrm{log} \cdot \mathrm{cfu} / \mathrm{ml}$. MM media as solid media supported for maximum conidial population $(9.56 \mathrm{log} \cdot \mathrm{cfu} / \mathrm{g})$ of the fungus, followed by WB $(9.50$ $\log \cdot \mathrm{cfu} / \mathrm{g}$ ) and RB (9.38 log.cfu/g) (Table 1 and Figures 2(a)-(d)). The result of liquid media (PDB and HE + PDB) observed in the present study is in accordance with the study by Akhila et al. [12]. They also tried mass culture of $P$. parasiticum in liquid media, and after 20 days of inoculation, the spore population in PDB was higher than the spore population in HE + PDB. Zhang et al. [16] reported that the Host Extract (HE) from the healthy part of Agar tree contains a low amount of Agawood oil compound as a defence agent against $P$. parasiticum. Hence, in the HE media or in the added HE media, the $P$. parasiticum growth was lower compared to the growth in other media. This result is in agreement 


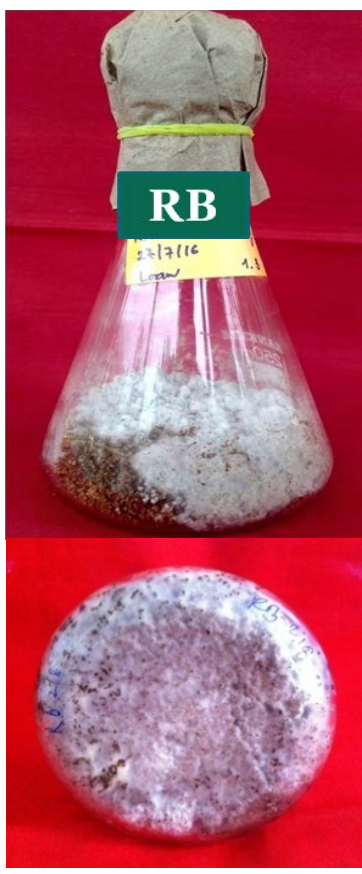

(a)

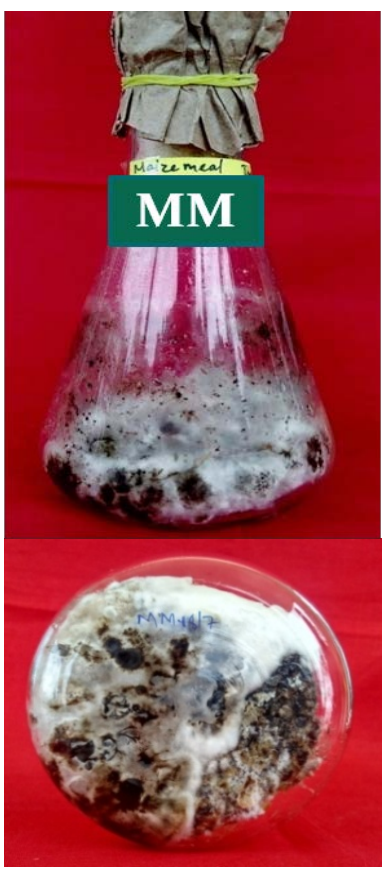

(b)

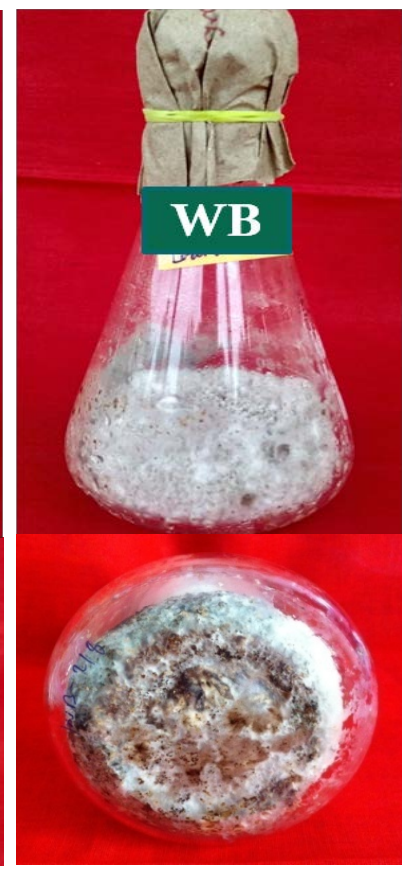

(c)

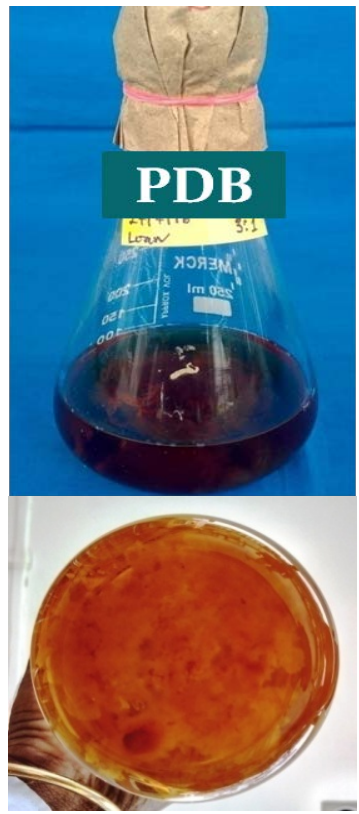

(d)

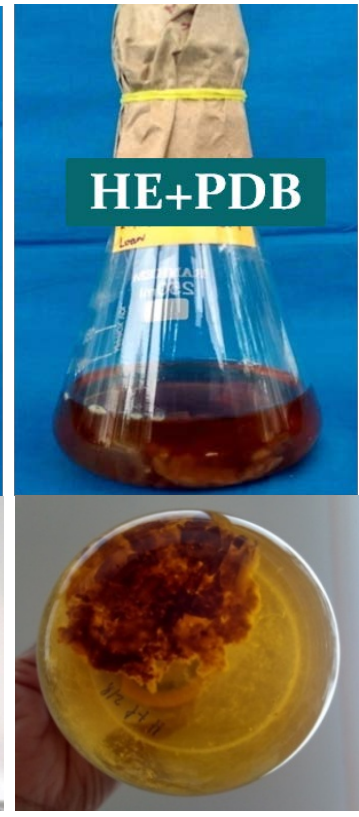

(e)

Figure 1. (a)-(d) Growth of $P$. parasiticumin different mass culture after 30 days of inoculation. (a) Rice bran; (b) Maize meal; (c) Wheat bran; (d) Potato dextrose broth; (e) Host extract (50\%) + PDB (50\%).

with various studies which stated that, the Agarwood extract originating from Agar trees exhibited strong antifungal activity against Fusariumsolani, F. oxysporum, Candida albicans, Lasiodiplodia theobromae [16] [17] [18] [19].

Mass culture of Beauveria bassiana was done by the several workers. According to each study, the best result of spore production in different media was 
Table 1. Population density of $P$. parasiticum in different culture media after 30 days of inoculation.

\begin{tabular}{ccc}
\hline Treatment & No. of $\mathbf{c f u} / \mathbf{g}$ or $\mathbf{~ m}^{*}$ & Log $\mathbf{c f u} / \mathbf{g}$ or $\mathbf{~ m l}^{* *}$ \\
\hline $\mathrm{T}_{1}$ : Rice Bran & $243 \times 10^{7}$ & $9.38^{\mathrm{c}}$ \\
$\mathrm{T}_{2}:$ Maize Meal & $367 \times 10^{7}$ & $9.56^{\mathrm{a}}$ \\
$\mathrm{T}_{3}:$ Potato Dextrose Broth (PDB) & $17 \times 10^{6}$ & $7.23^{\mathrm{d}}$ \\
$\mathrm{T}_{4}:$ Wheat Bran & $316 \times 10^{7}$ & $9.50^{\mathrm{ab}}$ \\
$\mathrm{T}_{5}:$ HE (50\%) + PDB (50\%) & $72 \times 10^{3}$ & $4.85^{\mathrm{e}}$ \\
$\mathrm{SEd}( \pm)$ & & 0.0571 \\
$\mathrm{CD}_{0.05}$ & & 0.1273 \\
\hline
\end{tabular}

${ }^{*}$ Mean of 25 replications; HE: Host Extract; ${ }^{* *}$ Mean within the same column followed by the same letter are not significant different at 0.05 level of probability.

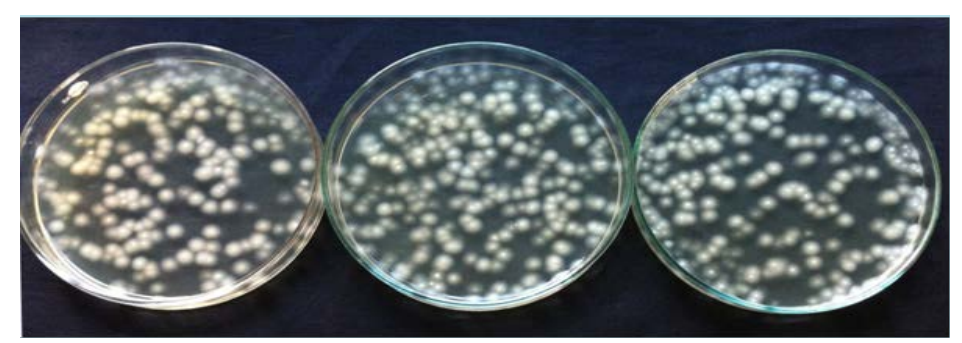

(a)

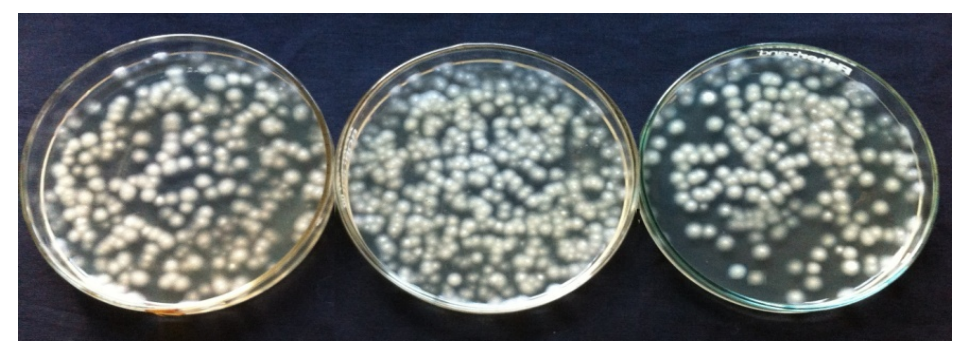

(b)

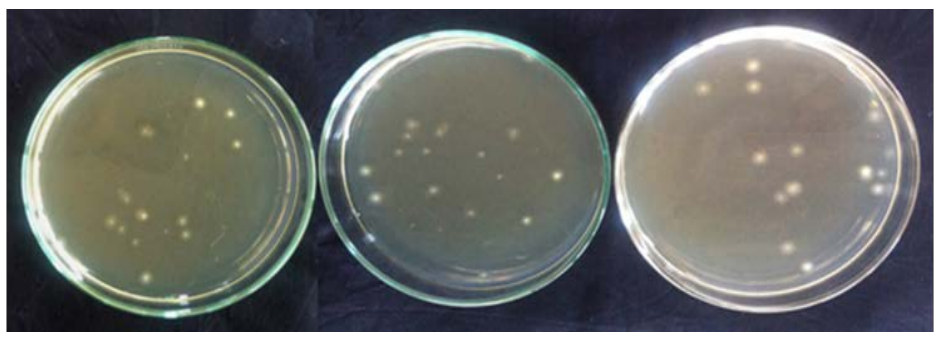

(c)

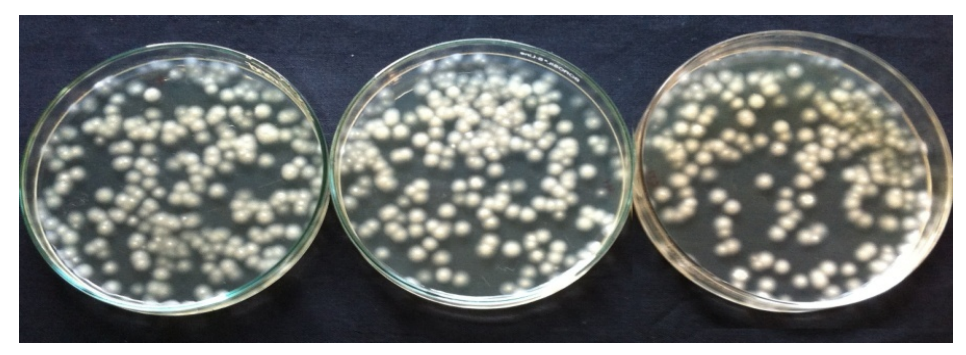

(d) 


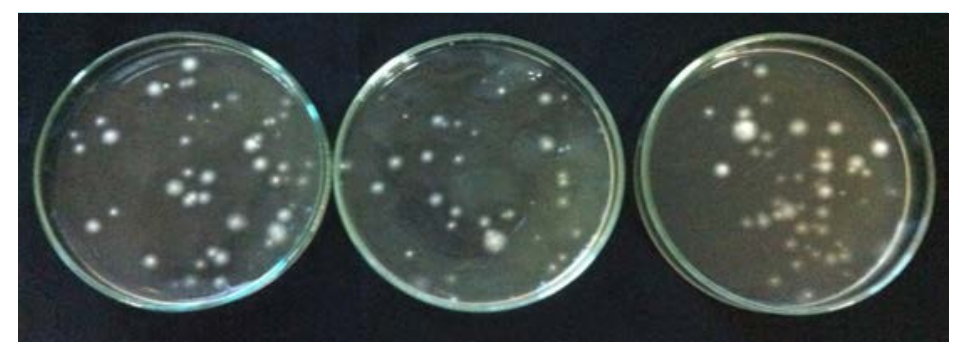

(e)

Figure 2. (a)-(e) Population density (cfu/g or $\mathrm{ml}$ ) of $P$. parasiticum in different mass culture media. (a) Rice bran ( $10^{-7}$ dilution); (b) Maize meal ( $10^{-7}$ dilution); (c) Potato dextrose broth $\left(10^{-6}\right.$ dilution); (d) Wheat bran $\left(10^{-7}\right.$ dilution); (e) Host extract $(50 \%)+$ potato dextrose broth $(50 \%)\left(10^{-3}\right.$ dilution).

showed as: in Rice flour liquid media $\left(2.4 \times 10^{8}\right.$ spores $\left./ \mathrm{ml}\right)$, and in Rice media $\left(6.24 \times 10^{4} \mathrm{spores} / \mathrm{g}\right)$ [20], in Cowpea solid media $\left(9.06 \times 10^{7}\right.$ spores/g) [21] Mass culture of Nomuraea rileyi showed the best spore production in Rice solid media $\left(5.53 \times 10^{7}\right.$ spore/g) and higher spore production in Wheat solid media $\left(3.55 \times 10^{7}\right.$ spores $\left./ g\right)$ [22]. In mass culture of Trichoderma viride, the highest conidial quantity assessment was in Potato Dextrose Agar $\left(91.89 \times 10^{8} \mathrm{cfu} / \mathrm{ml}\right)$ [23].

In mass culture production of Deuteromycetes fungi, solid media viz., Rice Bran (RB), Maize Meal (MM), Wheat Bran (WB) always are considered to be used for study because they are the common products, available, relatively cheaper and supporting both mycelia growth and spore production. Among those, Rice or Rice Bran usually gives the better result [24] [25] [26]. But in the present study, for mass culture of $P$. parasiticum, MM showed as the best substrate followed by WB. Maize contains high proportions of carbohydrates (starch), and to a lesser extent minerals, fats and proteins [27]. Lancey [28] stated that, because the whole maize is a good source of thiamin, pyridoxine and phosphorus, and a fair source of riboflavin, niacin, folate, biotin, iron and zinc, so maize meal is one of the favourite substrate for fungi development that many cause nutritional losses and production of toxic substances known as mycotoxin. According to Pollack and Benham [29], Maize meal was a well-established mycological medium used for the cultivation of fungi and to study chlamydospores production of various fungi.

Wheat Bran, a by-product of the dry milling of common Wheat, is one of the major agro-industrial by-products used in animal feeding. It consists of the outer layers (cuticle, pericarp and seedcoat) with small amount of starchy endosperm of the Wheat kernel. Wheat Bran has been used in fungal culture in laboratory as well as fungal mass culture in industrial scale [30].

The present study showed that, Maize Meal media (MM: Water $=100 \mathrm{~g}: 70 \mathrm{ml}$ ) at $\mathrm{pH}$ of 6.5 , incubation temperature: $30^{\circ} \mathrm{C} \pm 1^{\circ} \mathrm{C}$ for 30 days would be the standard technique for mass production of $P$. parasiticum. 


\section{References}

[1] Oldfield, S., Lusty, C. and MacKinven, A. (1998) The World List of Threatened Trees. World Conservation Press, Cambridge, 650 p.

[2] Chetpattananondh, P. (2012) Overview of the Agarwood Oil Industrial. 2012 Conference Proceedings of IFEAT International Conference, Singapore, 4-8 November 2012, 131-138.

[3] Antonopoulou, M., Compton, J., Perry, L.S. and Al-Mubarak, R. (2010) The Trade and Use of Agarwood (Oudh) in the United Arab Emirates. TRAFFIC, Petaling Jaya.

[4] Dash, M., Patra, J.K. and Panda, P.P. (2008) Phytochemical and Anti Microbial Screening of Extracts of Aquilaria agallocha Roxb. African Journal of Biotechnology, 7, 3531-3534.

[5] Mei, W.L., Zeng, Y.B., Wu, J., Cui, H.B. and Dai, H.F. (2008) Chemical Composition and Anti-MRSA Activity of the Essential Oil from Chinese Eaglewood. Journal of Chinese Pharmaceutical Sciences, 17, 225-229.

[6] Dinah, J. (2011) The Value of Agarwood: Reflections Upon Its Use and History in South Yemen. Extended Version of a Talk Given at the Workshop "The Use of Herbs in Yemeni Healing Practices", Halle, 25-26 September 2009.

[7] Saikia, G. (2006) Aquilariaagallocha (Agarwood): Prospect and Problems, Regional Workshop on Forestry Extension, July 14, 2006. Rain Fores Research Institute, Jorhat.

[8] Nguyen, L.T., Chang, Y.S. and Kadir, A.A. (1997) A Review on Agar (Gaharu) Producing Aquilaria Species. Journal of Tropical Forest Products, 2, 272-285.

[9] Akter, S., Islam, T., Zulkefeli, M. and Islam, K.S. (2013) Agarwood Production-A Multidisciplinary Field to Be Explored in Bangladesh. International Journal of Pharmaceutical and Life Sciences, 2, 22-32. https://doi.org/10.3329/ijpls.v2i1.15132

[10] Crous P.W., Gams, W., Wingfield, M.J. and Van Wyk, P.S. (1996) Phaeoacremonium gen. nov. Associated with Wilt and Decline Diseases of Woody Hosts and Human Infections. Mycologia, 88,786-796. https://doi.org/10.2307/3760973

[11] Akhila, G.V. (2015) Isolation, Characterization and Identification of the Organism Associated with Deposition of Oleoresin in Aquilaria malaccensis L. M.Sc. (Agri.) Thesis Submitted to Assam Agricultural University, Jorhat, 64.

[12] Akhila, G.V., Puzari, K.C. and Dutta, P. (2017) Establishment of the Optimum Temperature and $\mathrm{pH}$ for the Growth of Phaeoacremoniumparasiticum in Vitro and Standardization of the Media for Its Mass Culture. International Journal of Current Microbiology and Applied Sciences, 6, 147-154. https://doi.org/10.20546/ijcmas.2017.602.021

[13] Warcup, J.H. (1950) The Soil-Plate Method for Isolation of Fungi from Soil. Nature, 166, 117-118. https://doi.org/10.1038/166117b0

[14] Ajello, L., Georg, L.K., Steigbigel, R.T. and Wang, C.J.K. (1974) A Case of Phaeohyphomycosis Caused by a New Species of Phialophora. Mycology, 66, 490-498. https://doi.org/10.2307/3758492

[15] Mostert, L., Groenewald, J.Z., Summerbell, R.C., Gams, W. and Crous, P.W. (2006) Taxonomy and Pathology of Togninia (Diaportales) and Its Phaeoacremonium anamorphs. Studies in Mycology, 54, 1-113. https://doi.org/10.3114/sim.54.1.1

[16] Zhang, X.L., Liu, Y.Y. and Wei, J.H. (2012) Production of High-Quality Agarwood in Aquilariasinensis Trees via Whole-Tree Agarwood-Induction Technology. Chinese Chemical Letters, 23, 727-730. 
[17] Bhuiyan, M.N.I., Begum, J. and Bhuiyan, M.N.H. (2009) Analysis of Essential Oil of Eaglewood Tree (Aquilariaagallocha Roxb.) by Gas Chromatography Mass Spectrometry. Bangladesh Journal of Pharmacology, 4, 24-28.

[18] Wetwitayaklung, P., Thavanapong, N. and Charoenteeraboon, J. (2009) Chemical Constituents and Antimicrobial Activity of Essential Oil and Extracts of Heartwood of Aquilaria crassna Obtained from Water Distillation and Supercritical Fluid Carbon Dioxide Extraction. Silpakorn University Science and Technology Journal, 3, 25-33.

[19] Novriyanti, E., Santosa, E., Syafii, W., Turjaman, M. and Sitepu, I.R. (2010) Antifungal Activity of Wood Extract of Aquilariacrassna Pierre ex Lecomte against Agarwood-Inducing Fungi. Fusrium solani. Journal of Forestry Research, 7, 155-165.

[20] Latifian, M., Rad, B., Amani, M. and Rahkhodaei, E. (2013) Mass Production of Entomopathogenic Fungi Beauveriabassiana (Balsamo) by using Agricultural Products Based on Liquid-Solid Diphasic Method for Date Palm Pest Control. International Journal of Agriculture and Crop Sciences, 5, 2337-2341.

[21] Bhadautria, B.P., Puri, S. and Singh, P.K. (2012) Massproduction of Entomopathogenic Fungi using Agricultural Products. Bioscan, 7, 229-232.

[22] Thakre, M., Thakur, M., Malik, N. and Ganger, S. (2011) Mass Scale Cultivation of Entomopathogenic Fungus Nomuraearileyi using Agricultural Products and Agro Wastes. Journal of Biopesticides, 4, 176-179.

[23] Kumhar, K.C., Babu, A., Bordoloi, M. and Ali, A. (2015) Evaluation of Culture Media for Biomass Production of Trichodermaviride (KBN 24) and Their Production Economics. American Journal of Agriculture and Forestry, 2, 317-320.

[24] Ibrahim, Y.B. and Low, W. (1993) Potential of Mass Production and Field Efficacy of Isolates of the Entomopathoghenic Fungi Beauveriabassiana and Paecilomycesfumosoroseu on Plutellaxylostella. Journal of Invertebrate Pathology, 39, 222-232.

[25] Jenkins, N.E., Heriefo, G., Longewald, T., Cherry, A.J. and Lomer, C.J. (1998) Development of Mass Production Technology for Aerial Conidia for Use as Mycopesticides. Biocontrol News and Information, 19, 21-31.

[26] Sharma, S.P., Gupta, R.B.L. and Yadava, C.P.S. (2002) Selection of a Suitable Medium for Mass Multipication of Entomofungal Pathogens. Indian Journal of Entomology, 14, 255-261.

[27] Batool, S.A., Rauf, N., Tahir, S.S. and Kalsoom, R. (2012) Microbial and Physico-Chemical Contamination in the Wheat Flour of the Twin Cities of Pakistan. International Journal of Food Safety, 14, 75-82.

[28] Lancey, J. (1998) Prevention of Mould Growth and Mycotoxin Production through Control of Environmental Sector. Mycotoxin and Phycotoxin. Elisever, Amsterdam, 161-189.

[29] Pollack, J.D. and Benham, R.W. (1957) The Chlamydospores of Candida Albicans: Comparison of Three Media for Their Induction. Journal of Laboratory and Clinical Medicine, 50, 313.

[30] Fuller, M.F. (2004) The Encyclopedia of Farm Animal Nutrition. CABI Publishing Series, 606. https://doi.org/10.1079/9780851993690.0000 
Submit or recommend next manuscript to SCIRP and we will provide best service for you:

Accepting pre-submission inquiries through Email, Facebook, LinkedIn, Twitter, etc. A wide selection of journals (inclusive of 9 subjects, more than 200 journals)

Providing 24-hour high-quality service

User-friendly online submission system

Fair and swift peer-review system

Efficient typesetting and proofreading procedure

Display of the result of downloads and visits, as well as the number of cited articles Maximum dissemination of your research work

Submit your manuscript at: http://papersubmission.scirp.org/

Or contact ajps@scirp.org 